\title{
Somatic embryogenesis and genetic uniformity of regenerated cassava plants from low-temperature preserved secondary somatic cotyledons
}

\author{
Jelili T. OPABOde ${ }^{1^{*}}$, Olufemi V. AJibola ${ }^{1}$, OLUfEMi O. OYelakin ${ }^{2}$, OLUYemisi A. AKinyemiJu ${ }^{1}$ \\ ${ }^{1}$ Department of Crop Production and Protection, Obafemi Awolowo University, Ile-Ife, Nigeria \\ ${ }^{2}$ Center for Biotechnology, Federal University of Agriculture, Abeokuta, Nigeria
}

\begin{abstract}
Low plant regeneration and transformation frequencies in cassava have been attributed to recycling of cassava secondary somatic embryos for long periods. This study examined the suitability of low-temperature storage of dehydrated cassava secondary somatic embryos as an alternative short-term conservation approach to recycling. The study included two experiments: in the first one, somatic embryogenesis from cotyledons of dehydrated secondary somatic embryos stored at six temperatures for 4, 8 and 12 months was established; and in the second, plant regeneration via shoot organogenesis using somatic cotyledon explants obtained in the first experiment was examined. The growth, photosynthetic pigment contents and genetic stability of the regenerated plants were assessed. At each storage temperature, the survival of explants, somatic embryogenesis, shoot induction and elongation decreased with increases in storage period. At 4 months after storage (MAS), explant survival, frequency of somatic embryogenesis, shoot induction, elongation and rooting had the best responses at $16^{\circ} \mathrm{C}$ and $20^{\circ} \mathrm{C}$. Similarly, the growth and photosynthetic pigment contents of plants regenerated from somatic embryos preserved at $16^{\circ} \mathrm{C}$ and $20^{\circ} \mathrm{C}$ recorded the best results at $4 \mathrm{MAS}$. However, at 8 and $12 \mathrm{MAS}$, the best explant survival, somatic embryogenesis, shoot induction and elongation were recorded at $16^{\circ} \mathrm{C}$. Eight RAPD primers produced a total of 56 distinct and scorable bands, ranging from $250 \mathrm{bp}$ to $3000 \mathrm{bp}$ in size. An random amplified DNA (RAPD) analysis showed a uniform banding profile among regenerants and to that of the mother plant, indicating no genetic variation among regenerants and between the regenerants and the mother plant. The data presented here suggest that cassava secondary somatic embryos dehydrated to $50 \%$ moisture content should be preserved at $16-20^{\circ} \mathrm{C}$ for 4 months; for 8 and 12 months storage, the embryos should be stored at $16^{\circ} \mathrm{C}$. No genetic alteration was detected among the regenerants. Therefore, the method is a suitable means for short-term conservation of cassava secondary somatic embryos.
\end{abstract}

Key words: cassava, dehydration, low temperature, regeneration, somatic embryo

\section{Introduction}

An estimated 600 million people in tropical and subtropical climates depend on cassava (Manihot esculenta Crantz) as a source of energy (Defloor et al., 1998). The increase in cassava cultivation and its important role in food security are enhanced by two factors: the unique biology of the crop and the numerous ways its starch and by-products are being used, including its use as livestock feed, a source of bio-ethanol, and applications in food industry, and agrochemical and pharmaceutical industries (Nweke et al., 2002; El-Sharkawy, 2004). Cassava grows well on marginal soils and is tolerant of drought and soil acidity (El-Sharkawy, 2004). There is flexibility in harvesting, as tubers can be stored in the soil for a fairly long period, which ensures convenience in processing and marketing (Nassar and Ortiz, 2010). The global demand for cassava starch is rising and it is highly competitive and the preferred starch in comparison to conventional sources of starch such as wheat, corn, rice and potato (Nweke et al., 2002).

Despite its potential for achieving food security and economic growth, biotic and abiotic constraints such as

\footnotetext{
* Corresponding author: Department of Crop Production and Protection, Obafemi Awolowo University, 220005 Ile-Ife, Nigeria; e-mail: jopabode@yahoo.com
} 
diseases, pests, weeds, poor soil fertility and drought are bottlenecks to cassava production (Ceballos et al., 2004; Bull et al., 2011). Other problems facing cassava cultivation include postharvest physiological deterioration, high cyanide content, low protein content and fluctuating starch quality (Bull et al., 2011). The application of conventional breeding methods for the improvement of cassava against biotic and abiotic constraints has limited success (Nassar and Ortiz, 2010; Ceballos et al., 2004). Conventional breeding of cassava is challenging due to the highly heterozygous nature of the crop, which prevents a backcross scheme. This problem is exacerbated by the poor flowering and limited seed set of many varieties (Ceballos et al., 2004). In addition, carrying out sexual crosses in cassava is difficult and inbreeding depression is common. This problem is compounded by limited sources of genetic resistance to most abiotic and biotic stresses (Ceballos et al., 2004; Bull et al., 2011). In the field, cassava is typically propagated clonally by stem cuttings. This propagation strategy is ideal for a bio-engineering approach to crop improvement as gene segregation through outcrossing is limited. Successful genetic modification by bio-engineering requires the establishment of in vitro regeneration and transformation systems (Taylor et al. 2004; Osorio et al. 2012).

To date, the only reported means of incorporating foreign pieces of DNA into the cassava genome is via regeneration through somatic embryogenesis. As a result, somatic embryogenesis has become an integral component of the genetic transformation system of cassava (Taylor et al. 2004; Osorio et al. 2012; Raemakers et al., 2000). More than 60 African cassava cultivars, and other cultivars from South America and Asia, have been tested for their somatic embryo-producing ability. Currently, genetic modification of cassava is a relatively long-term process, arising from the recalcitrance of many varieties to gene transfer by either Agrobacterium or particle bombardment systems (Taylor et al., 2004). Sub-culturing and recycling of secondary somatic embryos for a lengthy period of time serve as constant sources of explants required for genetic transformation studies. However, recycling of cassava secondary somatic embryos is cumbersome and reduces the frequency and efficiency of somatic embryogenesis regeneration and transformation (Bull et al., 2011; Opabode et al., 2014). Variations in the morphology of the embryos, inconsistency in the duration of development of the embryos and increased callus size and frequency have been noted (Opabode et al., 2014). In addition, the recycling of somatic embryos induces genetic alteration as a result of the stress imposed on the plant tissues in culture, which is incorporated in the form of DNA methylation, chromosome rearrangements and point mutations (Phillips et al., 1994; Nadha et al., 2011).

To overcome the aforementioned challenges associated with lengthy recycling of secondary somatic embryos, there is need to establish a simple, low-cost, short-term in vitro preservation procedure for cassava somatic embryos to serve as a reliable source of explants for regeneration and genetic transformation. So far, only Mathews et al. (1993) have employed desiccation to achieve enhanced (83\%) plantlet recovery from somatic embryos dehydrated to $17 \%$ moisture content in cassava. In other plant species, dehydration of somatic embryos was used as a means of germplasm conservation in addition to the improvement in plant regeneration. For examples, the storage of dehydrated somatic embryos of carrot and grapevine under low temperatures has been investigated (Shao-Xing et al. 1992; Janyasankar et al., 2005). In carrots, Shao-Xing (1992) observed $67 \%$ conversion of dried somatic embryo to plantlets after four months of storage. Similarly, Jayasankar et al. (2005) reported that $90 \%$ of somatic embryos dehydrated to $17 \%$ moisture content in grapevine (a temperate species) regenerated into plants after 42 months of storage at $4{ }^{\circ} \mathrm{C}$. To our knowledge, somatic embryogenesis and plant regeneration from low-temperature preserved cassava somatic embryo has not been reported.

The objectives of the study were to: 1 ) induce somatic embryogenesis from dehydrated secondary somatic embryos kept at low temperatures for 4, 8 and 12 months; 2) examine plant regeneration via shoot organogenesis using somatic cotyledon explants obtained in (1);3) evaluate the growth and photosynthetic pigment content in regenerated plants; and 4) assess the genetic uniformity of regenerated plants by RAPD markers.

\section{Materials and methods}

\section{Basal medium and culture conditions}

A basal medium (BM) was used in all experiments, unless otherwise stated. The BM consisted of full-strength MS (Murashige and Skoog, 1962) salt (Sigma-Aldrich, USA) along with $0.8 \%$ (w/v) agar (Oxoid Ltd., England) and $30 \mathrm{~g} / \mathrm{l}$ sucrose. The $\mathrm{pH}$ of the medium was adjusted 
to 5.8 with $\mathrm{HCl}(1 \mathrm{~N})$ or $\mathrm{NaOH}(1 \mathrm{~N})$, prior to autoclaving at $121^{\circ} \mathrm{C}$ for $15 \mathrm{~min}$ at $1.05 \mathrm{kgcm}^{-2}$ pressure. Growth regulators were filter-sterilized through $0.22-\mu \mathrm{M}$ Millipore filters and added to media after autoclaving. For all experiments, except where otherwise stated, cultures were maintained in a 16 -h photoperiod with $20-\mu \mathrm{mol} \mathrm{m} \mathrm{m}^{-2}$ light intensity provided by cool-white fluorescent tubes at $25 \pm 2^{\circ} \mathrm{C}$.

\section{Production of primary and secondary somatic embryos}

Primary and secondary somatic embryos were produced as described by Li et al. (1998). For the production of primary somatic embryos, nodal segment explants were excised from three-week-old in vitro plantlets of cassava variety TME 12 and incubated in the dark on $\mathrm{BM}$ with $10 \mathrm{mg} / \mathrm{l}$ benzylaminopurine (BAP) for seven days for the enlargement of the axillary buds. Shoot meristems $(1-2 \mathrm{~mm})$ were isolated from the enlarged axillary buds. The isolated shoot meristems were incubated in the dark on BM with $10 \mathrm{mg} / \mathrm{l}$ of picloram for 17 days for induction of primary somatic embryos. Callused meristems with pre-embryogenic structures were then incubated in the dark on BM with $0.1 \mathrm{mg} / \mathrm{l} \mathrm{BAP}$ for 10 days for maturation of primary somatic embryos. For induction of secondary somatic embryos, cotyledons of primary somatic embryos were cut to about $4-6 \mathrm{~mm}^{2}$ size and incubated in the dark on BM with $6 \mathrm{mg} / \mathrm{l}$ of 2, 4-dichlorophenoxyacetic acid (2,4-D) for 14 days. Callused explants with pre-embryogenic structures were transferred onto $\mathrm{BM}$ with $0.1 \mathrm{mg} / 1 \mathrm{BAP}$ for maturation of secondary embryos. All somatic secondary embryo cultures were kept in the dark at $25 \pm 2^{\circ} \mathrm{C}$ for the present study. The viability $(98 \% \pm 3.5)$ of the secondary somatic embryos had previously been established by incubating pieces of secondary somatic cotyledon on BM with $6.0 \mathrm{mg} / \mathrm{l}$ of $2,4-\mathrm{D}$ under light to generate green somatic embryos prior to the genetic modification study (Oyelakin et al., 2015).

\section{Dehydration and low-temperature storage of secondary somatic embryos}

For the purpose of dehydration, 1350 cotyledonarystage secondary somatic embryos were carefully removed from the solid medium on which they had developed under sterile conditions. The embryos were collected in a $1500-\mathrm{mm}$ sieve and washed twice with sterile distilled water to remove nutrient medium. After washing, the embryos were blot-dried with sterile Kimwipes ${ }^{\mathrm{TM}}$ and placed on sterile filter paper in a laminar flow hood. The embryos were allowed to dehydrate until they had lost their moist appearance (approximately $4 \mathrm{~h}$ ). The amount of weight change due to water loss was determined by weighing samples of 100 somatic embryos before and after drying. After dehydration, embryos were removed from the filter paper and placed (approximately 20) in empty sterile Petri dishes $(90 \times 15 \mathrm{~mm})$ which were sealed with a double layer of Parafilm ${ }^{\mathrm{TM}}$ and stored in the dark at six $\left(4,8,12,16,20,25^{\circ} \mathrm{C}\right)$ temperatures for 4,8 and 12 months. $25^{\circ} \mathrm{C}$, the culture temperature at which the somatic embryos were initially produced, served as the control for the experiment.

Experiment 1: Effect of low-temperature storage of dehydrated secondary somatic embryos on the induction of somatic embryogenesis

To provide starting material for plant regeneration via shoot organogenesis, a green somatic embryo (somatic embryogenesis) was induced from a cotyledon of dehydrated secondary somatic embryos stored at $4^{\circ} \mathrm{C}$, $8^{\circ} \mathrm{C}, 12^{\circ} \mathrm{C}, 16^{\circ} \mathrm{C}, 20^{\circ} \mathrm{C}$ and $25^{\circ} \mathrm{C}$ for 4,8 and 12 months separately, as outlined by Opabode et al. (2013). Cotyledons of dehydrated secondary somatic embryos were harvested and cut to pieces of about $5 \mathrm{~mm}$ in size to serve as explants for the induction of green somatic embryos. The cotyledonal explants were cultured on BM with $6.0 \mathrm{mg} / \mathrm{l}$ of 2,4-D under light for the induction of somatic embryogenesis. Reponses of the explants were monitored daily with the aid of microscopes. After three weeks of incubation, cultures were scored for the presence of embryogenic structures in the developing callus. Thereafter, the developing callus with embryogenic structures was transferred to BM with $0.1 \mathrm{mg} / \mathrm{l}$ of BAP for maturation. The frequency of green somatic embryos and the mean number of somatic embryos per explant on the maturation medium after four weeks under light were recorded. Each Petri dish contained 20 explants and a total of 200 explants were used per treatment for both induction and maturation of somatic embryos.

Experiment 2: Effect of low-temperature storage of dehydrated secondary somatic embryos on shoot induction, elongation and rooting from the dehydrated somatic cotyledon

To facilitate plant regeneration, shoot induction and elongation (shoot organogenesis) were achieved as outlined by Li et al. (1998). Cotyledons of green somatic 
embryos obtained from the first experiment were cut into $6 \mathrm{~mm}$ pieces. The cotyledon pieces were cultured on $\mathrm{BM}$ with $1.0 \mathrm{mg} / \mathrm{l} \mathrm{BAP}$ and $0.5 \mathrm{mg} / \mathrm{l}$ indole-3-butyric acid (IBA) (Sigma-Adrich, USA) and incubated under light. The frequency of shootbud formation and the number of shootbuds per explant were recorded 14 days after incubation in the light. Thereafter, shootbuds were detached from the explants and transferred to BM with $1.0 \mathrm{mg} / \mathrm{l} \mathrm{BAP}$ and $10.0 \mathrm{IBA} \mathrm{mg} / \mathrm{l}$ for shoot elongation. The frequency of shoot elongation was recorded three weeks after the transfer. Thereafter, elongated shoots were excised and transferred on a hormone-free basic medium for rooting, as outlined by Li et al. (1998). The frequency of root formation and the number of roots per plantlet were recorded three weeks after culture. Each Petri dish contained 20 explants and a total of $200 \mathrm{ex}$ plants were used per treatment for both shoot induction and elongation, while 150 explants per treatment were used for rooting of elongated shoots.

\section{Hardening of plantlets and soil establishment of regenerated plants}

Cassava plantlets with well-developed roots obtained from the second experiment were rinsed with water to wash off the agar medium and transplanted to peat pellets (AS Jiffy Products Ltd, Norway) in plastic pots that were covered to maintain high humidity. The plants were grown at $22-26^{\circ} \mathrm{C}$ in a containment facility for 3 weeks and transferred to a greenhouse, where they were grown to maturity. Plants were raised in polybags filled with a rich loamy soil with the following properties: $\mathrm{pH}$ $=7.2$, organic carbon $=4.3 \%$, total nitrogen $=5.1 \%$, cation exchange capacity $=15.3 \mathrm{cmol} / \mathrm{kg}$ and textural class = clay loam.

\section{Growth rate and photosynthetic pigment content} of regenerated plants

To further assess the impact of the dehydration of secondary somatic embryos on regenerated plants, the growth rate and photosynthetic pigments of the plants obtained from the second experiment were measured. Dry weights were determined on six tagged uniform plants per treatment when plants were three and six months old. Dry weights of three tagged plants per treatment were determined at each time point and averaged. The growth rate (GR) was determined from the relationship, GR $=\mathrm{W}_{2}-\mathrm{W}_{1} / \mathrm{t}_{2}-\mathrm{t}_{1}$, where $\mathrm{W}_{2}$ and $\mathrm{W}_{1}$ are dry weights at two successive time points: $t_{2}$ and $t_{1}$. Pig- ments were extracted from fresh leaves ( $1 \mathrm{~g}$ ) with $80 \%$ acetone following homogenization. The homogenized mixture was separated by centrifugation at $5000 \times g$ for $10 \mathrm{~min}$. The absorbances of the supernatant were read at the following wavelengths with a spectrophotometer: 645, 653, 662 and $664 \mathrm{~nm}$, for chlorophyll a and b and $470 \mathrm{~nm}$ for carotene, as outlined by Lichtentaler and Wellburn (1985). Measurements were performed in triplicates. Equations used for calculations are presented below:

Chlorophyll a $=11.75$ A662 -2.350 A645

Chlorophyll b $=18.61$ A645 -3.960 A662

Carotenoids $=1000 \mathrm{~A} 470-2.270 \mathrm{Chl} \mathrm{a}-81.4 \mathrm{Chl} \mathrm{b} / 227$

\section{DNA Extraction and RAPD analysis}

To determine the genetic stability of the regenerated plants obtained from dehydrated somatic embryos by RAPD markers, DNA was extracted from young leaves (0.5-1.0 g) of 3- and 6-month-old regenerated plants. The DNA was extracted as described by Dellaporta et al. 1983. The crude DNA was purified with RNase A followed by washing thrice with phenol/chloroform/isoamyl alcohol $(25: 24: 1 \mathrm{v} / \mathrm{v} / \mathrm{v})$ and subsequently with chloroform/isoamyl alcohol $(24: 1 \mathrm{v} / \mathrm{v})$. Quantification of DNA was performed with a Nanodrop spectrophotometer. The quality of the DNA was verified by running $2 \mu$ l of the DNA alongside a molecular weight marker Pst I on $1 \%$ agarose gel in $1 \mathrm{X}$ TAE (Tris Acetate EDTA) buffer at $500 \mathrm{~V}$ for one hour. DNA samples were diluted to $25 \mathrm{ng} / \mu \mathrm{l}$ for RAPD-PCR analysis. A total of eight random decamer primers (Operon Tech, Alameda, USA) from B, $\mathrm{C}$, D, and E series (OPB06, OPB08, OPB12, OPC01, OPC02, OPC05, OPC06, OPE19) were used for RAPD analysis. The primers were selected on the basis of the results and clarity of a banding pattern from previous studies (Angel et al., 1996; Herzberg et al., 2004). The RAPD analysis was performed as described by Williams et al. (1990). PCR was performed in a volume of $25 \mu \mathrm{l}$ containing $25 \mathrm{ng}$ of template DNA, $2.5 \mathrm{ml}$ of $10 \mathrm{X}$ assay buffer $(100 \mathrm{mM}$ Tris-HCl, $\mathrm{pH} 8.3,500 \mathrm{mM} \mathrm{KCl}$ and $0.1 \%$ gelatin), $1.5 \mathrm{mM} \mathrm{MgCl}_{2}, 200 \mu \mathrm{M}$ each of dNTPs, $15 \mathrm{ng}$ of primer, 0.5 U Taq DNA polymerase (Bioline, USA). DNA amplification was performed in a thermal cycler (PTC 2000, MJ Research, India). The first step consisted of holding the samples at $94^{\circ} \mathrm{C}$ for $5 \mathrm{~min}$ for complete denaturation of the template DNA. The second step consisted of 42 cycles with three ranges of temperature, 
i.e. at $92^{\circ} \mathrm{C}$ for $1 \mathrm{~min}$ denaturation of template DNA, at $37^{\circ} \mathrm{C}$ for $1 \mathrm{~min}$ for primer annealing and at $72^{\circ} \mathrm{C}$ for $2 \mathrm{~min}$ for primer extension followed by running the samples at $72^{\circ} \mathrm{C}$ for $7 \mathrm{~min}$ for complete polymerization. The PCR products were electrophoresed in 1.5\% agarose gel containing ethidium bromide $[0.5 \mu \mathrm{g} / \mathrm{ml}$ of gel solution in TAE buffer ( $40 \mathrm{mM}$ Tris, $20 \mathrm{~mm}$ acetic acid, $20 \mathrm{~mm}$ EDTA to $\mathrm{pH} 8$ )] for $3 \mathrm{~h}$ at $60 \mathrm{~V}$. The size of the amplicons was determined using size standards: a GeneRuler 100 bp DNA Ladder Plus. DNA fingerprints were visualized under UV light and photographed using a gel documenting system (Bio-Rad, CA, USA). The RAPD analysis using each primer was repeated at least twice to establish the reproducibility of the banding pattern of different DNA samples of cassava.

\section{Experimental design and statistical analysis}

In all experiments, treatments were arranged in a completely randomized design with three replicates, and experiments were repeated twice. The count and percentage data were not normally distributed; therefore, a square root transformation on count data and $\operatorname{arc} \sin \sqrt{x}$ transformation on percentage data were performed, respectively, before the analysis of variance. The data were further subjected to an analysis of variance to detect differences among treatments using the PROC GLM procedure of the Statistical Analysis Systems (SAS 2002). The means were separated by Tukey's test at a $5 \%$ level of probability.

\section{Results}

Effect of low-temperature storage of dehydrated secondary somatic embryo on the induction of somatic embryogenesis

A slight change from light yellow (Fig. 1A) to gray (1B) occurred in the color of the cotyledons of somatic embryos after drying for four hours in the air current of a laminar flow hood. An average 50\% loss in weight occurred after subjecting the embryos to 4 hours of dehydration. As evidenced by their increase in size, cotyledons of dehydrated secondary somatic embryos placed on BM became hydrated within 55 minutes, and reverted to the light yellow appearance (Fig. 1C) characteristic of non-dehydrated secondary somatic embryo cotyledons. Further enlargement and callus formation, indicative of survival, occurred within one week of transfer on BM (Fig. 1D). Bipolar structures had occurred by the second week and by the third week, somatic embryos with green cotyledons had developed (Fig. 1E). The survival of dehydrated secondary somatic cotyledons was measured by hydration, swelling and callus formation upon culturing on $\mathrm{BM}$ with $6.0 \mathrm{mg} / \mathrm{l}$ of 2,4-D under light for induction of somatic embryogenesis. Storage of dehydrated secondary somatic cotyledons at low temperatures significantly $(P<0.05)$ influenced their survival, the frequency of somatic embryogenesis and the number of embryos per explant at all periods of storage. As the period of storage was increased, the survival of dehydrated secondary somatic cotyledon decreased (Table 1). At 4 MAS, survival of dehydrated secondary somatic cotyledons increased with increasing storage temperature. At 8 and 12 MAS, survival of dehydrated secondary somatic cotyledons was best at 16 and $20^{\circ} \mathrm{C}$. Similarly, the frequency of somatic embryogenesis decreased as the period of storage increased. By 12 MAS, no formation of somatic embryos was recorded at $4^{\circ} \mathrm{C}$. The best somatic embryogenesis frequency was obtained at $16^{\circ} \mathrm{C}$ at 8 and 12 MAS. At 4 MAS, the largest number of somatic embryos was produced at $25^{\circ} \mathrm{C}$. However, at 8 and 12 MAS, the largest number of somatic embryos was produced at $16^{\circ} \mathrm{C}$.

Effect of low-temperature storage of dehydrated secondary somatic embryos on shoot induction, elongation and rooting

To further confirm the regenerative ability of green somatic embryos obtained from cotyledons of dehydrated secondary somatic embryos, shoot organogenesis was initiated from surfaces of the green somatic cotyledon pieces (Fig. 2A) on a shoot induction medium. By the second week of incubation, shoot primordials had established on the cotyledon surfaces (Fig. 2B) and by the third week shootbuds (Fig. 2C) had become visible. The percentage shoot induction and the number of shoots per explants were significantly $(P<0.05)$ influenced by the storage of dehydrated secondary somatic embryos at low temperatures (Table 2). Shoot induction from green somatic cotyledons obtained from dehydrated secondary somatic embryos stored for four months increased with an increase in storage temperature up to $16^{\circ} \mathrm{C}$ and remained non-significantly different thereafter. However, the formation of shootbuds by green somatic cotyledons obtained from dehydrated somatic cotyledons stored for eight months increased with an increase in sto- 


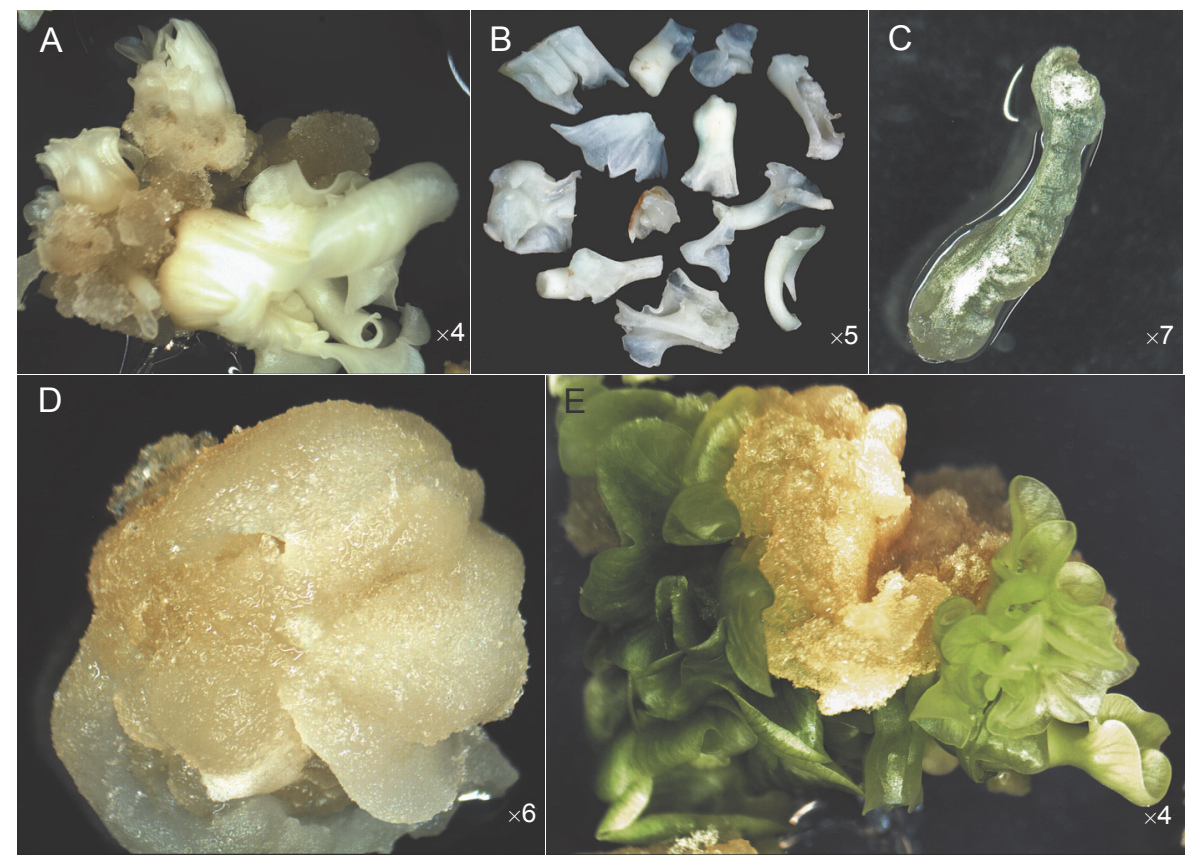

Fig. 1. Somatic embryogenesis from dehydrated secondary somatic embryos preserved at low temperatures. A) Secondary somatic embryos developed from primary somatic embryos used for the study; B) isolated dehydrated secondary somatic embryos; C) re-hydrated secondary somatic embryo cotyledon after 12 months storage at $16^{\circ} \mathrm{C}$; D) Embryogenic callus obtained from secondary somatic embryo cotyledon kept at $16^{\circ} \mathrm{C}$ for 12 months; E) Green somatic embryos developed from a secondary somatic embryo cotyledon kept for 12 months at $16^{\circ} \mathrm{C}$
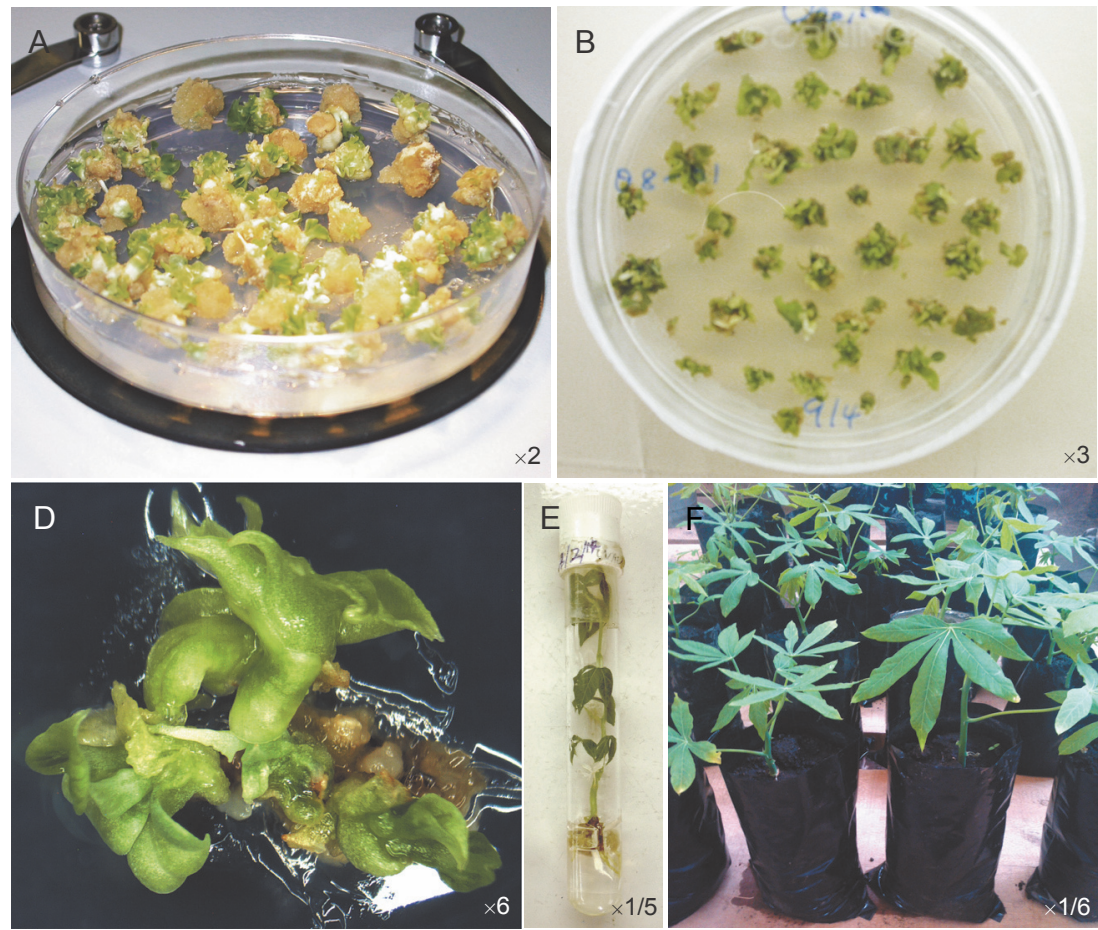

Fig. 2. Regeneration from dehydrated secondary somatic embryos preserved at low temperatures: A) green somatic embryos developing from a secondary somatic embryo cotyledon kept for 12 months at $16^{\circ} \mathrm{C}$; B) shoot induction from green somatic cotyledon pieces obtained from a secondary somatic embryo cotyledon kept for 12 months at $16^{\circ} \mathrm{C}$; C) elongation of shootbuds from green somatic cotyledon pieces obtained from a secondary somatic embryo cotyledon kept for 12 months at $16^{\circ} \mathrm{C}$; D) rooting of elongated shoot obtained from green somatic cotyledon pieces obtained from secondary somatic embryo cotyledon kept for 12 months at $16^{\circ} \mathrm{C}$; E) growing regenerated plants following hardening 
Table 1. Effect of storage of dehydrated secondary somatic embryos at low temperatures for 4, 8 and 12 months on survival of explant and somatic embryogenesis

\begin{tabular}{|c|c|c|c|c|c|c|c|c|c|}
\hline \multirow{2}{*}{$\begin{array}{c}\text { Temperature } \\
\left({ }^{\circ} \mathrm{C}\right)\end{array}$} & \multicolumn{3}{|c|}{4 MAS } & \multicolumn{3}{|c|}{8 MAS } & \multicolumn{3}{|c|}{12 MAS } \\
\hline & $\mathrm{S}(\%)$ & SE (\%) & $\mathrm{N} / \mathrm{E}$ & $\mathrm{S}(\%)$ & $\mathrm{SE}(\%)$ & $\mathrm{N} / \mathrm{E}$ & $\mathrm{S}(\%)$ & SE (\%) & $\mathrm{N} / \mathrm{E}$ \\
\hline 4 & $45.2 \pm 2.3 \mathrm{c}$ & $15.9 \pm 3.1 \mathrm{c}$ & $4.5 \pm 5.6 \mathrm{c}$ & $13.5 \pm 2.5 \mathrm{c}$ & $3.2 \pm 2.0 \mathrm{c}$ & $4.0 \pm 1.3 \mathrm{~d}$ & $12.5 \pm 2.1 b$ & $0.0 \pm 0.0 \mathrm{~d}$ & $0.0 \pm 0.0 \mathrm{e}$ \\
\hline 8 & $48.3 \pm 2.8 \mathrm{c}$ & $15.4 \pm 2.9 \mathrm{c}$ & $4.4 \pm 7.8 \mathrm{c}$ & $18.4 \pm 2.4 \mathrm{c}$ & $3.4 \pm 1.5 c$ & $4.1 \pm 1.2 \mathrm{~d}$ & $12.7 \pm 0.4 \mathrm{~b}$ & $2.3 \pm 0.0 \mathrm{~d}$ & $2.0 \pm 0.0 \mathrm{e}$ \\
\hline 12 & $66.8 \pm 5.3 \mathrm{~b}$ & $27.5 \pm 3.1 b$ & $15.6 \pm 5.3 \mathrm{~b}$ & $23.4 \pm 3.8 \mathrm{~b}$ & $7.4 \pm 2.5 b$ & $10.3 \pm 3.5 \mathrm{~b}$ & $15.8 \pm 1.5 b$ & $4.6 \pm 1.6 \mathrm{c}$ & $7.3 \pm 1.4 \mathrm{c}$ \\
\hline 16 & $74.1 \pm 3.5 \mathrm{a}$ & $46.7 \pm 3.4 \mathrm{a}$ & $16.7 \pm 7.4 \mathrm{~b}$ & $45.9 \pm 4.3 \mathrm{a}$ & $23.2 \pm 2.3 \mathrm{a}$ & $16.4 \pm 6.3 \mathrm{a}$ & $40.2 \pm 1.3 \mathrm{a}$ & $15.8 \pm 1.8 \mathrm{a}$ & $15.1 \pm 2.4 \mathrm{a}$ \\
\hline 20 & $74.3 \pm 2.1 \mathrm{a}$ & $45.2 \pm 3.8 \mathrm{a}$ & $22.2 \pm 9.3 \mathrm{a}$ & $43.6 \pm 3.4 \mathrm{a}$ & $10.3 \pm 1.3 \mathrm{a}$ & $11.2 \pm 2.4 \mathrm{~b}$ & $35.5 \pm 1.6 \mathrm{a}$ & $10.9 \pm 0.6 \mathrm{~b}$ & $10.3 \pm 3.4 \mathrm{~b}$ \\
\hline 25 & $75.7 \pm 3.5 \mathrm{a}$ & $12.8 \pm 2.1 \mathrm{c}$ & $24.5 \pm 6.7 \mathrm{a}$ & $14.6 \pm 3.2 \mathrm{c}$ & $2.6 \pm 2.7 \mathrm{c}$ & $6.3 \pm 2.5 \mathrm{c}$ & $7.5 \pm 2.7 \mathrm{c}$ & $6.1 \pm 0.0 \mathrm{c}$ & $4.2 \pm 2.3 \mathrm{~d}$ \\
\hline
\end{tabular}

Values are means ( \pm standard error) of three replicates. Means followed by different letters in same column are significantly different at $5 \%$ level of probability according to Tukey Test.

MAS - month after storage S- survival of cotyledon explants SE- frequency of somatic embryogenesis N/E - number of embryo per explant 
Table 2. Shoot induction and number of shoot per explant of somatic embryos obtained from dehydrated embryo cotyledon kept at low temperatures for 4,8 and 12 months

\begin{tabular}{c|c|c|c|c|c|c}
\hline \multirow{2}{*}{$\begin{array}{c}\text { Temperature } \\
\left({ }^{\circ} \mathrm{C}\right)\end{array}$} & \multicolumn{2}{|c|}{4 MAS } & \multicolumn{2}{c}{$8 \mathrm{MAS}$} & \multicolumn{2}{c}{12 MAS } \\
\cline { 2 - 7 } & SI (\%) & NS/explant & SI $(\%)$ & NS/explant & SI (\%) & NS/explant \\
\hline 4 & $5.4 \pm 4.3 \mathrm{~d}$ & $4.3 \pm 0.4 \mathrm{c}$ & $2.6 \pm 9.7 \mathrm{~d}$ & $4.0 \pm 0.4 \mathrm{c}$ & - & - \\
\hline 8 & $14.3 \pm 4.6 \mathrm{c}$ & $4.1 \pm 0.7 \mathrm{c}$ & $8.5 \pm 3.6 \mathrm{~d}$ & $4.0 \pm 0.4 \mathrm{c}$ & $1.1 \pm 1.6 \mathrm{~d}$ & $3.2 \pm 0.3 \mathrm{~b}$ \\
\hline 12 & $51.1 \pm 3.6 \mathrm{~b}$ & $5.2 \pm 0.8 \mathrm{c}$ & $28.0 \pm 3.4 \mathrm{c}$ & $4.1 \pm 0.5 \mathrm{c}$ & $3.6 \pm 2.8 \mathrm{~d}$ & $3.4 \pm 0.4 \mathrm{~b}$ \\
\hline 16 & $82.5 \pm 3.1 \mathrm{a}$ & $6.5 \pm 0.6 \mathrm{a}$ & $72.7 \pm 2.7 \mathrm{a}$ & $6.0 \pm 0.4 \mathrm{a}$ & $54.6 \pm 2.0 \mathrm{a}$ & $5.1 \pm 0.2 \mathrm{a}$ \\
\hline 20 & $81.4 \pm 2.1 \mathrm{a}$ & $6.5 \pm 0.5 \mathrm{a}$ & $52.2 \pm 2.0 \mathrm{~b}$ & $5.5 \pm 0.5 \mathrm{~b}$ & $34.8 \pm 2.1 \mathrm{~b}$ & $4.4 \pm 0.1 \mathrm{~b}$ \\
\hline 25 (control) & $82.6 \pm 2.0 \mathrm{a}$ & $6.0 \pm 0.4 \mathrm{~b}$ & $34.8 \pm 1.8 \mathrm{c}$ & $4.0 \pm 0.3 \mathrm{c}$ & $20.0 \pm 1.0 \mathrm{c}$ & $3.3 \pm 0.0 \mathrm{~b}$ \\
\hline
\end{tabular}

Values are means ( \pm standard error) of three replicates; means followed by different letters in same column are significantly different at $5 \%$ level of probability according to Tukey Test; MAS - month after storage, SI - shoot induction, NS - number of shoot
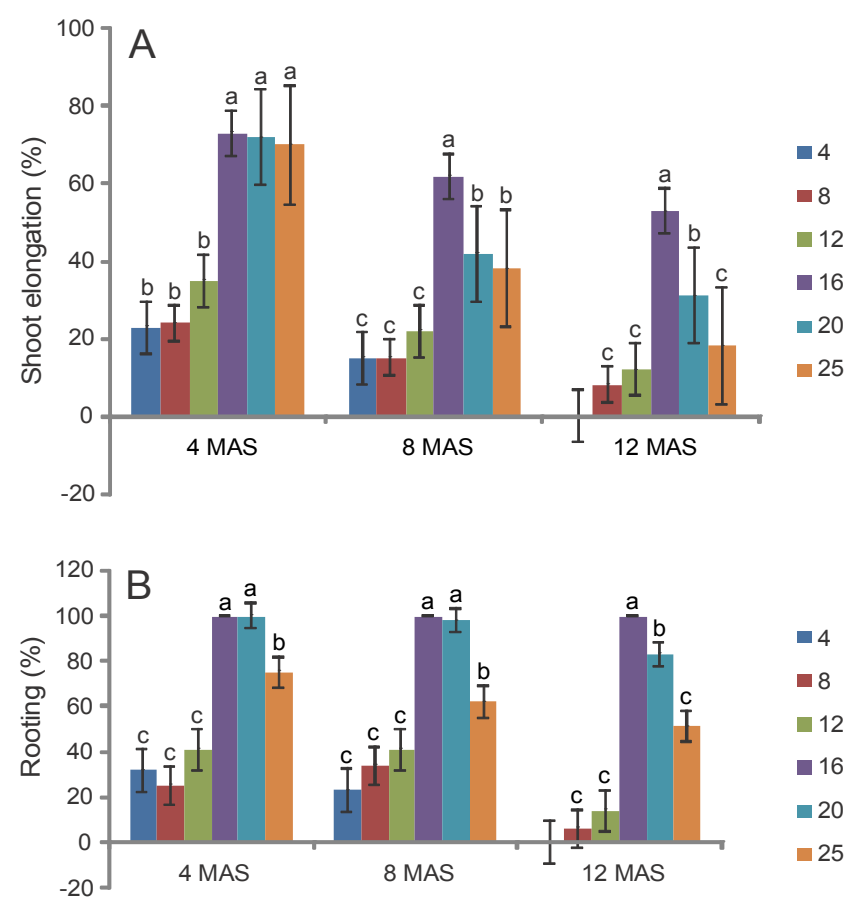

Fig. 3. Shoot elongation and root formation of regenerated plants obtained from dehydrated secondary somatic embryos kept at low temperatures for 4, 8 and 12 months

rage temperature up to $16^{\circ} \mathrm{C}$, but decreased thereafter. At 12 MAS, shoot induction occurred at $8^{\circ} \mathrm{C}$ and increased sharply with an increase in temperature, before declining with the best shoot induction recorded at $16^{\circ} \mathrm{C}$. The numbers of shootbuds per explant increased as storage temperature increased up to $16^{\circ} \mathrm{C}$ before subsequently declining. Consequently, the best number of shootbuds per explant from green somatic cotyledons obtained from cotyledons of dehydrated secondary somatic embryos stored for 8 and 12 months occurred at $16^{\circ} \mathrm{C}$.
Again, the storage of dehydrated secondary somatic embryos at low temperatures had a significant $(P<0.05)$ impact on the ability of shootbuds to elongate and on the formation of roots by elongated shoots. Shootbuds formed by green somatic cotyledons obtained from secondary somatic embryos stored at $16^{\circ} \mathrm{C}, 20^{\circ} \mathrm{C}$ and $25^{\circ} \mathrm{C}$ for four months recorded the best shoot elongation. However, shoot elongation was best at $16^{\circ} \mathrm{C}$ at 8 and 12 MAS. At 4, 8 and 12 MAS, shoot elongation was lowest at $4{ }^{\circ} \mathrm{C}, 8^{\circ} \mathrm{C}$ and $12^{\circ} \mathrm{C}$. In addition, shoot elongation ability decreased as the storage period increased. However, the root formation ability of the elongated shoot was not influenced by storage period experienced by dehydrated secondary somatic embryos. Elongated shoots produced roots on a hormone-free medium at all temperatures and storage periods, and formed plantlets but at varying proportions. The lowest percentage rooting was recorded at $4^{\circ} \mathrm{C}, 8^{\circ} \mathrm{C}$ and $12^{\circ} \mathrm{C}$. All elongated shoots (100\%) transferred on hormone-free medium produced roots at 16 and $20^{\circ} \mathrm{C}$ at 4 and $8 \mathrm{MAS}$. Similarly, $100 \%$ elongated shoots produced roots at $16^{\circ} \mathrm{C}$ at 12 MAS. No plantlets were lost during the hardening of regenerated plants or their establishment in the soil.

\section{Growth rate, and carotenoid and chlorophyll contents of regenerated plants as influenced by low-temperature storage of dehydrated secondary somatic embryos}

The impact of the storage of dehydrated secondary somatic cotyledons at low temperatures is reflected significantly $(P<0.05)$ in the growth rate and carotenoid contents of regenerated plants (Fig. 4). At 4 MAS, plants obtained from dehydrated secondary somatic embryos preserved at 16 and $20^{\circ} \mathrm{C}$ recorded the highest growth 

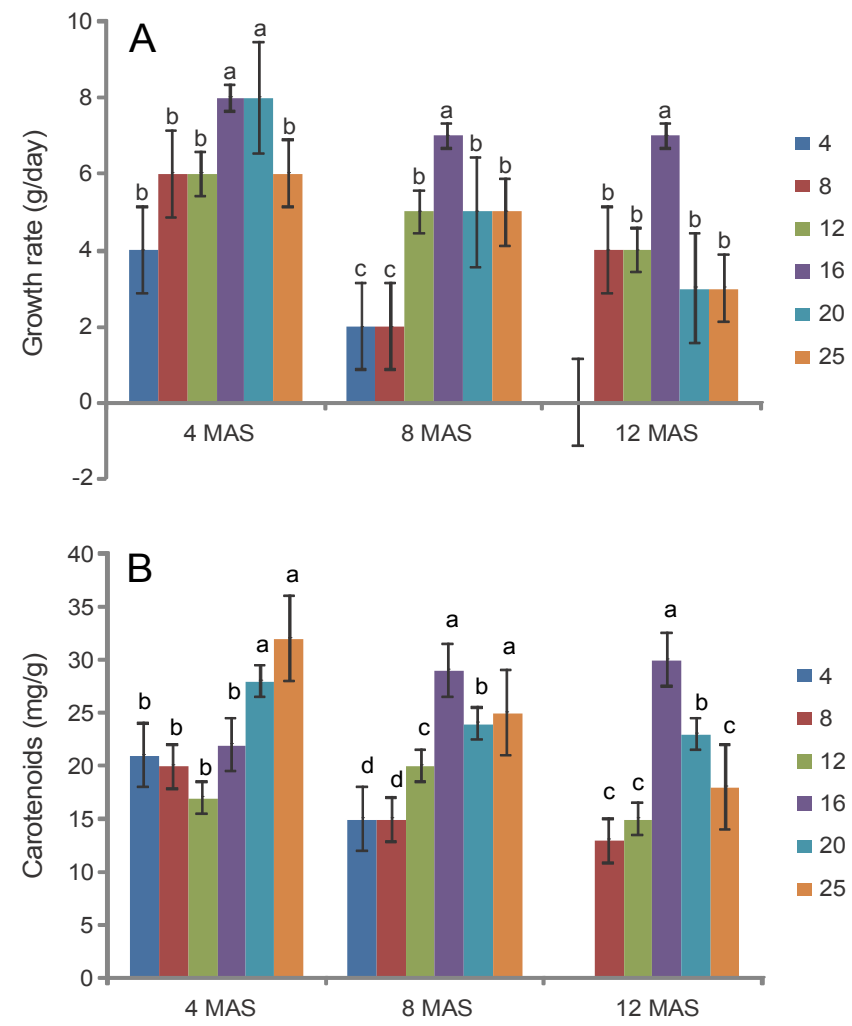

Fig. 4. Growth rate and carotenoid content of regenerated plants obtained from dehydrated secondary somatic embryos kept at low temperatures for 4, 8 and 12 months
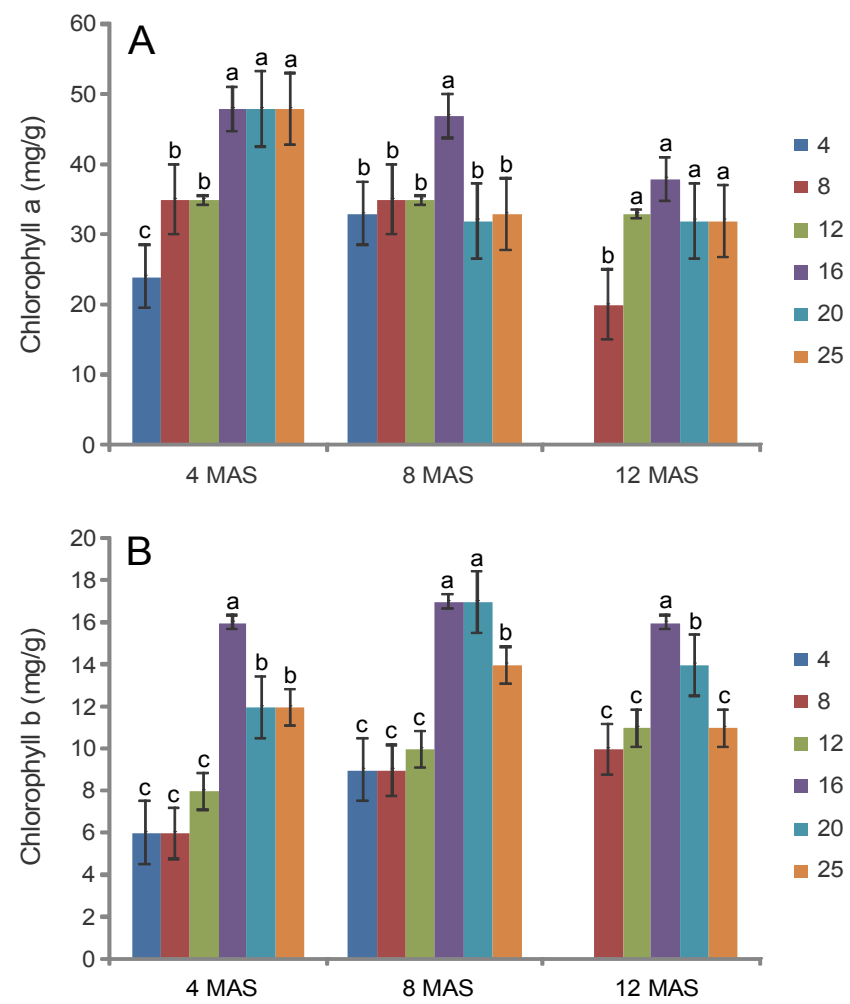

Fig. 5. Leaf chlorophyll a and b contents of regenerated plants obtained from dehydrated secondary somatic embryos kept at low temperatures for 4,8 and 12 months rate (Fig. 4). However, at 8 and 12 MAS, plants obtained from dehydrated secondary somatic embryos preserved at $16^{\circ} \mathrm{C}$ recorded the highest growth rates, while the lowest growth rates were observed at $4{ }^{\circ} \mathrm{C}$ and $8^{\circ} \mathrm{C}$. At 4 MAS, the largest carotenoid content was observed in plants obtained from secondary somatic embryos kept at $20^{\circ} \mathrm{C}$ and $25^{\circ} \mathrm{C}$. However, at 8 and 12 MAS, the largest quantities of carotenoids were produced by plants derived from secondary somatic embryos preserved at $16^{\circ} \mathrm{C}$, while the lowest quantities were produced by plants derived from secondary somatic embryos preserved at $4{ }^{\circ} \mathrm{C}$ and $8^{\circ} \mathrm{C}$. Also, leaf chlorophyll content was influenced by the low temperature storage of dehydrated secondary somatic embryos (Fig. 5). At 4 MAS, plants produced from secondary somatic embryos stored at $16^{\circ} \mathrm{C}, 20^{\circ} \mathrm{C}$ and $25^{\circ} \mathrm{C}$ recorded the greatest quantity of chlorophyll a. However, plants obtained from secondary somatic embryos preserved at $16^{\circ} \mathrm{C}$ produced the largest quantity of chlorophyll a at 8 MAS. At 12 MAS, plants obtained from secondary somatic embryos kept at $12^{\circ} \mathrm{C}$, $16^{\circ} \mathrm{C}, 20^{\circ} \mathrm{C}$ and $25^{\circ} \mathrm{C}$ recorded higher chlorophyll a. However, the largest quantities of chlorophyll b were obtained from plants derived from secondary somatic embryos stored at $16^{\circ} \mathrm{C}$ at all storage periods. Plants developed from secondary somatic embryos kept at $8^{\circ} \mathrm{C}$ and $12^{\circ} \mathrm{C}$ consistently recorded the least chl. $\mathrm{b}$ at all storage periods.

\section{Molecular analysis of regenerated plants by RAPD markers}

To establish the genetic integrity of plants obtained from dehydrated secondary somatic embryos kept at low temperatures for short periods, an RAPD analysis was conducted when plants were 3 and 6 months old. The DNA of a total of 37 plants across treatments and a mother plant were analyzed. In this study, the RAPD technique generated a total of 2072 bands from all plants analyzed with eight selected primers. The bands produced monomorphic patterns across all 37 plants analyzed. Eight selected RAPD primers utilized in this study gave rise to a total of 56 distinct and scorable bands, ranging from $250 \mathrm{bp}$ to $3000 \mathrm{bp}$ in size (Table 3). The number of bands for each primer varied from 4 to 12 , with an average of 7 bands per RAPD primer. The number of monomorphic bands was the highest (12) in the case of primer OPB12, ranging from 450 to $3000 \mathrm{bp}$ in size and the lowest (4) in the case of primer $\mathrm{OPC} 02$, 
Table 3. Properties and amplification products of RAPD primers used for the study

\begin{tabular}{c|c|c|c|c|c}
\hline $\mathrm{s} / \mathrm{n}$ & Primer & Sequence & GC $\%$ & No bands & Range of applicon \\
\hline 1 & OPB-06 & TGCTCTGCCC & 70 & 05 & $200-1000$ \\
\hline 2 & OPB-08 & GTCCACACGG & 70 & 09 & $250-1050$ \\
\hline 3 & OPB-12 & CCTTGACGCA & 60 & 12 & $450-3000$ \\
\hline 4 & OPC-01 & TTCGAGCCAG & 60 & 07 & $250-2000$ \\
\hline 5 & OPC-02 & GTGAGGCGTC & 70 & 04 & $500-750$ \\
\hline 6 & OPC-05 & GATGACCGCC & 70 & 05 & $350-2800$ \\
\hline 7 & OPC-06 & GAACGGACTC & 60 & 08 & $300-3000$ \\
\hline 8 & OPE-19 & ACGGCGTATG & 60 & 06 & $450-2000$ \\
\hline
\end{tabular}

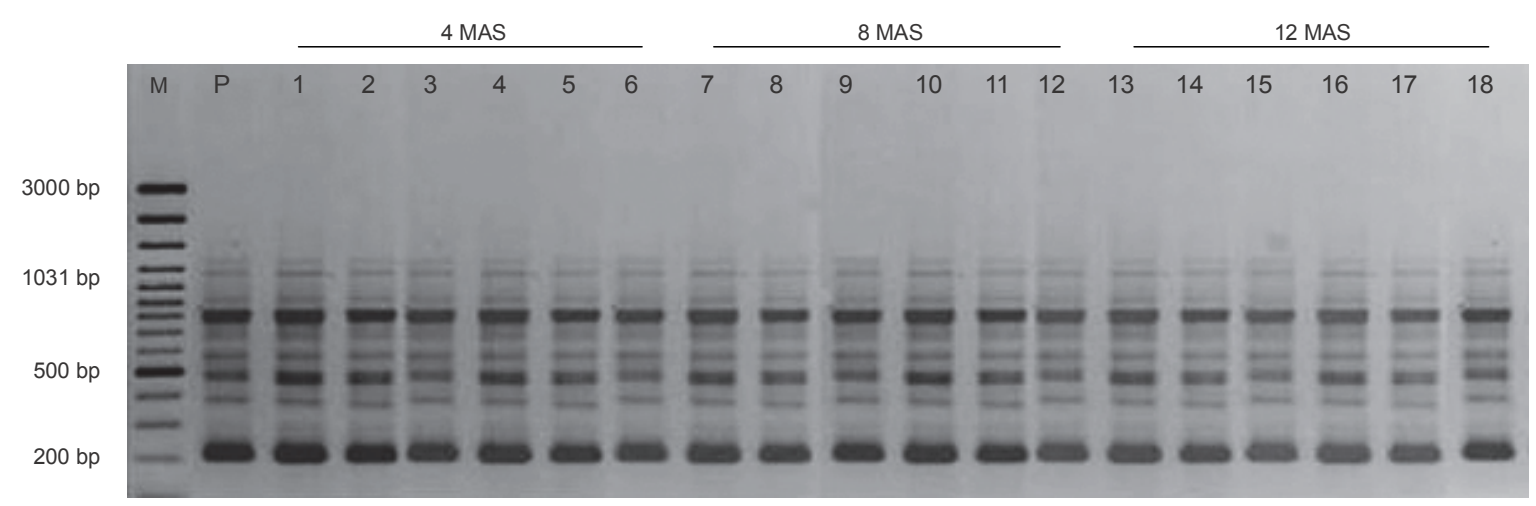

Fig. 6. Randomly amplified polymorphic DNA analysis for the primer OPB06: M - GeneRuler ladder, P - Mother plant, 1-6 - randomly selected samples of regenerated plants obtained from dehydrated secondary somatic embryos kept at $16^{\circ} \mathrm{C}$ for 4 months, 7-12 - randomly selected samples of regenerated plants obtained from dehydrated secondary somatic embryos kept at $16^{\circ} \mathrm{C}$ for 8 months, $13-18$ - randomly selected samples of regenerated plants obtained from dehydrated secondary somatic embryos kept at $16^{\circ} \mathrm{C}$ for 12 months

ranging from 500 to $750 \mathrm{bp}$ in size. The RAPD banding pattern showing monomorphic bands obtained among 18 6-month old regenerants is shown in Figure 6. The RAPD analysis of regenerated plants from cassava variety TME 12 showed a profile similar to that of the mother plant, indicating that there was no genetic variation between the regenerants and the mother plant.

\section{Discussion}

The influence of the storage of dehydrated secondary somatic embryos at $4^{\circ} \mathrm{C}, 8^{\circ} \mathrm{C}, 12^{\circ} \mathrm{C}, 16^{\circ} \mathrm{C}, 20^{\circ} \mathrm{C}$ and $25^{\circ} \mathrm{C}$ for 4,8 and 12 months on somatic embryogenesis and regeneration from the cotyledons of dehydrated secondary somatic embryos and genetic uniformity, growth and photosynthetic pigments of regenerated plants was investigated in two experiments. In the first experiment, somatic embryogenesis from dehydrated secondary somatic cotyledons stored at low temperatures was established and plant regeneration via shoot organogenesis using somatic cotyledon explants obtained in the first experiment was achieved in the second experiment. Next, the growth, photosynthetic pigment content and genetic uniformity of the regenerated plants were assessed.

At all storage temperatures and periods, dehydrated secondary somatic cotyledons survived when transferred onto a medium for induction of somatic embryogenesis which ranged from 7.5 to $75.7 \%$. Somatic embryogenesis and plant regeneration at all storage temperatures and periods were established, except at $4^{\circ} \mathrm{C}$ MAS. However, the best somatic embryogenesis and plant regeneration were recorded at $16-20^{\circ} \mathrm{C}$ at $4 \mathrm{MAS}$ and $16^{\circ} \mathrm{C}$ at 8 and 12 MAS, as revealed by the frequency of somatic em- 
bryos, the mean number of embryos per explant, the shoot induction and elongation and root formation. Earlier, dehydration of somatic embryos had been employed to enhance germination and plant recovery from somatic embryos in crops including cassava. Mathews et al. (1993) obtained $92 \%$ germination and $83 \%$ plant regeneration from $83 \%$ desiccated cyclic globular embryos in cassava. The main differences between the results of our study and observations reported by Mathew et al. (1993) are: the low temperature storage of dehydrated somatic cotyledons included in the present study, the type of somatic embryo (globular vs cotyledonary) and cassava variety (Mcol 1505 vs TME 12). Similarly, in vitro shoot cultures of cassava accessions were maintained at $16-25^{\circ} \mathrm{C}$ (slow growth conditions) for 10 years with regenerative ability of the shoot cultures ranging from 46.6 to $76.3 \%$ (as reported by Angel et al. (1996)). Also, in a study on the effects of desiccation and different storage period on the vigor of somatic embryos of carrots, Shao-Xing (1992) observed 67\% conversion of dried somatic embryos to plantlets after four months of storage at room temperature. Recently, Jayasankar et al. (2005) reported that $90 \%$ of dehydrated somatic embryos of grapevine (a temperate species) regenerated into plants after 42 months of storage at $4{ }^{\circ} \mathrm{C}$. Also, Corredoira et al. (2008) reported that drying in a laminar flow hood for two hours reduced the somatic embryo moisture content to $57-58 \%$ and enhanced the potential plant recovery in chestnuts by $37 \%$ after two months of cold storage at $4{ }^{\circ} \mathrm{C}$. In the present study, the removal of cyclic somatic embryos from the culture medium, dehydration of the embryos and preservation of dehydrated embryos under low temperatures starved and denied the embryos of sucrose, which imposed stress on the embryos and, possibly, caused dormancy. According to Corredoira et al. (2008), dehydration arrests growth and physiological processes, and thereby triggers dormancy; while low temperature reduces the rate of metabolic and physiological processes, a condition that promotes conservation. Furthermore, the reduction of water content in embryos has been reported to trigger the tolerance mechanism by reducing turgor, alteration of osmotic balance and rapid biochemical changes due to differences in the soluble protein pattern (Rance et al., 1994; Black et al., 1999). To explain the improvement in plantlet recovery from a dehydrated somatic embryo following starvation stress, Lee et al. (2001) hypothesized that starva- tion and water loss stimulate synchronization of the tissue toward the development of existing embryos instead of the proliferation of undifferentiated cells and or additional pro-embryos.

We established shoot organogenesis from cotyledons of somatic embryos obtained from dehydrated cotyledons which demonstrated the high regenerative ability of the embryos. The statistical significance of low temperature treatments on shoot induction, elongation, rooting, growth and photosynthetic pigment content implies that the effect of low temperature does not terminate at somatic embryogenesis, but continues to manifest itself at different stages of growth at both morphological and physiological levels. Shoot elongation was more difficult than shoot induction. Previously, shoot primordia had been successfully induced on pieces of cotyledons derived from non-dehydrated cassava secondary somatic embryos on a medium containing $0.5 \mathrm{mg} / \mathrm{l} \mathrm{BA}$ and $0.1 \mathrm{mg} / \mathrm{IBA}$ followed by shoot elongation and rooting ( $\mathrm{Li}$ et al., 1998; Hankoua et al. 2005). The loss of regenerative ability could explain the decreased shoot and root formation as the storage period increased. High storage temperatures $\left(20^{\circ} \mathrm{C}\right.$ and $\left.25^{\circ} \mathrm{C}\right)$ might have promoted deterioration of somatic embryos, while low temperatures $\left(4-12^{\circ} \mathrm{C}\right)$ drastically reduced the regenerative ability of somatic embryos of cassava, since cassava originated in the tropics. According to Bekheet and Taha (2013), temperate species are preserved best at $4{ }^{\circ} \mathrm{C}$, whereas tropical plants require temperatures in the range of 15 $20^{\circ} \mathrm{C}$ for best conservation. A similar trend was observed by Jayasankar et al. (2005), who reported that $90 \%$ of dehydrated somatic embryos of grapevine (a temperate species) regenerated into plants after 42 months of storage at $4{ }^{\circ} \mathrm{C}$. In the present study, the best shoot induction at 12 months of storage was $54.6 \%$ at $16^{\circ} \mathrm{C}$ which compared with 59 and $25.5 \%$ shoot induction reported by Li et al. (1998) and Hankoua et al. (2005), respectively, from non-dehydrated secondary somatic embryos of cassava.

The results of this study established the genetic uniformity of plants regenerated from dehydrated secondary somatic embryos kept at low temperatures for a maximum of 12 months by an RAPD analysis. The RAPD analysis in the present study revealed a similarity at the DNA level among the plants derived from dehydrated secondary somatic embryos stored at a low temperature for a maximum period of 12 months. Furthermore, 
the RAPD analysis showed the genetic uniformity between the mother plant and the regenerants. Earlier, Angel et al. (1996) had demonstrated the genetic stability of in vitro cultured cassava germplasm when they reported the stability of cassava plants at the DNA level after retrieval from 10 years of in vitro storage by a slow growth method using a combination of RAPD and RFLP primers. Similarly, Hankoua et al. (2005) established the genetic stability of field-grown cassava plants derived from somatic embryos by flow cytometry by confirming that the DNA content of regenerants was homogeneous and similar to that of mother plants and that the ploidy level was unchanged $(2 n=36)$. RAPD markers have been able to assess the genetic stability of in vitro propagated plants of almonds (Martins et al., 2004), ginger (Mohanty et al., 2008), air potato (Dioscorea bulbifera L.) (Dixit et al., 2003), yams (Ahuja et al., 2002), bamboo (Nadha et al., 2011), and banana (Lakshmana et al., 2007).

In conclusion, for the first time somatic embryogenesis and plant regeneration were established from cassava secondary somatic embryos dehydrated to $50 \%$ moisture content and stored for 4, 8 and 12 months at low temperatures. Explant survival, somatic embryogenesis, shoot induction, elongation and rooting suggested that $16^{\circ} \mathrm{C}$ and $20^{\circ} \mathrm{C}$ are suitable temperatures for preserving cassava secondary somatic embryos dehydrated to $50 \%$ moisture content for four months. However, for storage of the embryos for 8 and 12 months, $16^{\circ} \mathrm{C}$ is the most suitable temperature. The RAPD analysis revealed the genetic uniformity of plants regenerated from dehydrated secondary somatic embryos kept at low temperatures for 4, 8 and 12 months. Similarity at the molecular level was also established by an RAPD analysis between the mother plant and regenerated plants. Most importantly, this study provides an alternative means of maintaining the regenerative ability of cassava secondary somatic embryos. The procedure described here is simple, reproducible and compatible with the existing regeneration and transformation systems, as no chemical treatment of somatic embryos, which could have a negative impact on the regeneration and transformation efficiency, is involved. Although a decline in the regenerative ability of secondary somatic embryos was recorded, $54 \%$ shoot induction was recorded at 12 months after storage at $16^{\circ} \mathrm{C}$.

\section{Acknowledgements}

This study was supported by Obafemi Awolowo University Research Committee through grant No.11812AXP and the National Agency for Biotechnology Development (NABDA), Abuja, Nigeria.

\section{References}

Abdalla N.A., Ragab M.E., El-Deen S., El-Miniawy M., Taha H.S. (2013) Callus induction, regeneration and molecular characterization of cassava (Manihot esculenta Crantz). J. Appl. Sci. Res. 9: 3781-3790.

Ahuja S., Mandal B.B., Dixit S., Srivastava P.S. (2002) Molecular phenotypic and biosynthetic stability in Dioscorea floribunda plants derived from cryopreserved shoot tips. Plant Sci. 163: 971-97.

Angel F., Barney V.E. Tohme J., Roca W.M. (1996) Stability of cassava plants at the DNA level after retrieval from 10 years of in-vitro storage. Euphytica 90: 307-313.

Bekheet S.A., Taha H.S. (2013) Complementary strategy for conservation of date palm germplasm. Global J. Biodiv. Sci. Managt. 3: 96-107.

Black M., Corbineau F., Gee H., Côme D. (1999) Water content, raffinose, and dehydrins in the induction of desiccation tolerance in immature wheat embryos. Plant Physiol. 120: 463-471.

Bull S.E., Ndunguru J., Gruissem W., Beeching J.R, Vanderschuren H. (2011) Cassava: constraints to production and the transfer of biotechnology to African laboratories. Plant Cell Report 30: 677-679.

Ceballos H., Iglesias C.A, Pereze J.C., Dixon A.G.O. (2004) Cassava breeding: opportunities and challenges. Plant Mol. Biol. 56: 503-516.

Corredoira E., Valladares S., Vieitez A.M., Ballester A. (2008) Improved germination of somatic embryos and plant recovery of European chestnut. In Vitro Cell. Dev. Biol. Plant 44: 307-315.

Defloor I., Dehing I., Delcour J.A. (1998) Physico-chemical properties of cassava starch. Tropical Sci. 31: 189-207.

Dellaporta S.L., Wood J., Hicks J.B. (1983) A plant DNA mini preparation version II. Plant Biotech. Mol. Biol. Rep. 1: 19-21.

Dixit S., Mandal B.B., Ahuja S., Srivastava P.S. (2003) Genetic stability assessment of plants regenerated from cryopreserved embryogenic tissues of Dioscorea bulbifera $L$. using RAPD, biochemical and morphological analysis. Cryo Lett. 24: 77-84.

El-Sharkawy M.A. (2004) Cassava biology and physiology. Plant Mol. Biol. 56: 481-501.

Hankoua B.B., Ng S.Y.C, Fawole I., Pouti-Kaerlas J., Pillay M., Dixon A.G.O. (2005) Regeneration of a wide range of African cassava genotypes via shoot organogenesis from cotyledons of maturing somatic embryos and conformity of field-established regenerants. Plant Cell Tiss. Org. Cult. 82: 221-231. 
Herzberg F., Mahungu N.M., Mignouna J., Kullaya A. (2004) Assessment of genetic diversity of local varieties of cas sava in Tanzania using molecular markers. Afr. Crop Sci. J. 12: 171-187.

Jayasankar S., Aman M.V., Cordts J. Dhekney S., Li L.T., Gray D.J. (2005) Low temperature storage of suspension culture-derived grapevine somatic embryos and regeneration of plants. In Vitro Cell. Dev. Biol. Plant 41: 752-756.

Lakshmanan V., Venkataramareddy S.R., Neelwarne B. (2007) Molecular analysis of genetic stability in long-term micropropagated shoots of banana using RAPD and ISSR markers. Elect. J. Biotech. 10: 1-8.

Lee E.-K., Cho D.-Y., Soh W.-Y. (2001) Enhanced production and germination of somatic embryos by temporary starvation in tissue cultures of Daucus carota. Plant Cell Rep. 20: 408-415.

Li H.Q., Guo J.Y., Huang Y.W., Liang C.Y., Liu H.X., Potrykus I., Puonti-Kaerlas J. (1998) Regeneration of cassava plants via shoot organogenesis. Plant Cell Rep. 17: 410-414.

Lichtenthaler H.K., Wellburn A.R. (1985) Determination of total carotenoids and chlorophylls $A$ and $B$ of leaf in different solvents. Biol. Soc. Trans. 11: 591-592.

Mathews H., Schopke C., Carcamo R., Chavarriaga P., Fauquet C., Beachy R.N. (1993) Improvement of somatic embryogenesis and plant recovery in cassava. Plant Cell Rep. 12: 328-333.

Martins M., Sarmento D., Oliveira M.M. (2004) Genetic stability of micropropagated almond plantlets as assessed by RAPD and ISSR markers. Plant Cell Rep. 23: 492-496.

Mohanty S., Panda M.K., Subudhi E., Acharya L. (2008) Genetic stability of micropropagated ginger derived from axillary bud through cytophotometric and RAPD analysis. $Z$. Naturforsch 63: 747-754.

Murashige T., Skoog F. (1962) A revised medium for rapid growth and bioassays with tobacco tissue cultures. Physiol. Planta. 15: 473-497.

Nadha H.K., Kumar R., Sharma R.K., Anand M., Sood A. (2011) Evaluation of clonal fidelity of in vitro raised plants of Guadua angustifolia Kunth using DNA-based markers. J. Med. Plants Res. 23: 5636-5641.

Nassar N., Ortiz R. (2010) Breeding cassava to feed the poor. Sci. Amer. 302: 78-84.
Nweke F.I., Spencer D.D.C., Lynam J.K. (2002) The cassava transformation, Michigan State University Press, East Lansing.

Opabode J.T., Oyelakin O.O., Akinyemiju O.A., Ingelbrecht I.L. (2013) Primary somatic embryos from axillary meristems and immature leaf lobes of selected African cassava varieties. Brit. Biotech. J. 3: 263-273.

Opabode J.T., Oyelakin O.O, Akinyemiju O.A., Ingelbrecht I.L. (2014) Influence of type and age of primary somatic embryo on secondary and cyclic somatic embryogenesis of cassava (Manihot esculenta Crantz). Brit. Biotech. J. 4: 254-269.

Osorio M., Gámez E., Molina S., Infante D. (2012) Evaluation of cassava plants generated by somatic embryogenesis at different stages of development using molecular markers. Elect. J. Biotech. 15. Available at: http://dx.doi.org/ $10.2225 /$ vol15- issue 4 - fulltext-3.

Oyelakin O.O., Opabode J.T., Raji A.A., Ingelbrecht I.L. (2015) A Cassava vein mosaic virus promoter cassette induces high and stable gene expression in clonally propagated transgenic cassava (Manihot esculenta Crantz). South Afri. J. Bot. 97: 184-190.

Phillips R.L., Kaeppler S.M., Olhoft P. (1994) Genetic instability of plant tissue cultures: breakdown of normal controls. Proc. Nat. Acad. Sci. USA 91: 5222-5226.

Raemakers K., Jacobsen E., Visser R. (2000) The use of somatic embryogenesis for plant propagation in cassava. Mol. Biotech. 14: 215-221.

Rance I.M., Tian W., Mathews H., Kochko A., Beachy R.N., Fauquet C. (1994) Partial desiccation of mature embryoderived calli, a simple treatment that dramatically enhances the regeneration ability of indica rice. Plant Cell Rep. 13: 647-651.

Shao-Xing H., Mei-Juan H. Cheng Z. (1992) Studies on the vigour of carrot somatic embryos enhances by desiccation. Acta Bot. Sinica 36: 145-150.

Taylor N.J., Chavarriaga P., Raemakers K., Siritunga D., Zhang P. (2004) Development and application of transgenic technologies in cassava. Plant Mol. Biol. 56: 671678. 